\title{
Functional overlap in the src gene family: inactivation of hck and fgr impairs natural immunity
}

\author{
Clifford A. Lowell, ${ }^{1}$ Philippe Soriano, ${ }^{2}$ and Harold E. Varmus ${ }^{1,3}$ \\ ${ }^{1}$ Department of Microbiology and Immunology and ${ }^{3}$ Biochemistry and Biophysics, University of California, San Francisco, \\ San Francisco, California 94143 USA; ${ }^{2}$ Fred Hutchinson Cancer Research Center, Seattle, Washington 98104 USA
}

\begin{abstract}
We have generated mice with targeted disruptions of the src-like genes hck and fgr to assess the role of these kinases in myeloid cell development and function. Hematopoiesis appears to proceed normally in both hck $^{-\prime-}$ and $\mathrm{fgr}^{-1-}$ animals, and in $\mathrm{hck}^{-1-}-\mathrm{fgr}^{-/-}$double homozygotes, but phagocytosis is impaired in $\mathrm{hck}^{-1-}$ macrophages. Macrophages cultured from doubly homozygous, $\mathrm{hck}^{-/}-\mathrm{fgr}^{-1-}$ animals retain many other normal functional properties, suggesting that the deficiency of these kinases is complemented by other src family members. The specific activity of the Lyn protein kinase is increased in hck ${ }^{-/-}$macrophages, implying that Lyn may compensate for a deficiency in Hck. Doubly mutant animals, however, have a novel immunodeficiency characterized by an increased susceptibility to infection with Listeria monocytogenes, indicating that either hck or fgr is required to maintain a normal natural immune response. These data provide the first direct example of genetic interactions between src gene family members.
\end{abstract}

[Key Words: kinase; src; macrophage; natural immunity]

Received December 7, 1993; accepted January 5, 1994.

Many protein-tyrosine kinases have been implicated in the signal transduction pathways by which extracellular ligands induce proliferation, differentiation, and functional activation of hematopoietic cells. Of these kinases, the proteins encoded by the src gene family members are among the best characterized. All nine src family members are expressed in various hematopoietic lineages, with many cell types expressing multiple members of the gene family (Bolen 1991; Bolen et al. 1992; Cooper and Howell 1993). The roles of src family gene products in various signal transduction pathways has been implied by (1) coassociation of Src kinases with cell surface receptors; $\{2\}$ stimulation of kinase activity following ligand binding to receptors; and $|3|$ the effects of overexpression or loss of kinase activity in isolated cell lines and transgenic mice. Some of these studies suggest that Src kinases may have overlapping or complementary roles in signal transduction pathways. For example, Fyn and Lck play central roles in T-cell receptor (TCR)mediated T-cell activation (Cooke et al. 1991; Appleby et al. 1992; Stein et al. 1992; Straus and Weiss 1992); Lyn and Yes are implicated in Fce receptor signal transduction in mast cells (Eiseman and Bolen 1992a,b); and Lck, Fyn, and Lyn are each involved in IL-2 signal transduction pathways in T cells (Hatakeyama et al. 1991; Kobayashi et al. 1993).

A genetic approach to this problem of overlapping function between Src kinases would involve looking for second site mutations that modify the phenotype of src family mutant animals. Such an approach has been used successfully to dissect the signal transduction pathways in which the Drosophila abl gene is involved (Hoffmann 1991). If two genes serve overlapping functions, mice made doubly mutant for each gene may manifest new phenotypes not found in single gene mutants. For example, myf-5 $5^{-1-}-$ myo $D^{-1-}$ mice have a complete block in skeletal muscle formation, a phenotype not seen in the single mutant animals, indicating that these genes play functionally redundant roles in myogenesis (Rudnicki et al. 1993). Although the effects of combined mutations within the src gene family have not been reported previously, the effects of single mutations suggest that the src family genes have overlapping or complementary functions. Thus, disruption of c-src results in an obvious defect in only one cell type, osteoclasts, despite nearly ubiquitous expression of the gene, with very high levels of expression of Src protein in neurons and platelets (Soriano et al. 1991; Lowe et al. 1993). Similarly, disruption of fyn produces defects in TCR signaling that are overcome as $T$ cells mature, suggesting that other kinases mediate signaling in peripheral $\mathrm{T}$ cells (Appleby et al. 1992; Stein et al. 1992).

hck and fgr encode $s r c$ family protein tyrosine kinases that are largely coexpressed and coregulated in hematopoietic cells. mRNAs for these kinases are found principally in terminally differentiated myelomonocytic cells, including neutrophils, monocytes, and macrophages (Holtzman et al. 1987; Quintrell et al. 1987 ; Zie- 
gler et al. 1987; Ley et al. 1989; Notario et al. 1989). hck mRNA is also found in low levels in B cells (Quintrell et al. 1987; Law et al. 1992), and fgr is expressed in NK cells (Inoue et al. 1990) and in Epstein-Barr virus-infected B cells (Gutkind et al. 1991). In monocytes and macrophages, synthesis of both hck and fgr mRNA is dramatically increased by activation with bacterial lipopolysaccharide (Ziegler et al. 1988; Yi and Willman 1989; Boulet et al. 1992). mRNAs encoding Hck and Fgr are also observed in leukemic cells that have initiated differentiation toward myelomonocytic lineages but not in undifferentiated cells or in cell lines arrested early in myelopoiesis (Willman et al. 1991). Hence, both kinases have been predicted to serve a role either in the terminal differentiation of myelomonocytic cells or in the specific functions of fully differentiated effector cells for natural immunity.

To seek the functions of $h c k$ and $f g r$ in hematopoietic cell development and function and to look for evidence of complementation between these genes, we have generated $h c k$ - and $f g r$-deficient mice using gene targeting in embryonic stem (ES) cells and have bred these animals together to generate double homozygotes. Hematopoietic development appears normal in single and doubly mutant animals; however, phagocytosis is impaired in $h_{c k}{ }^{-1-}$ macrophages. On the other hand, doubly mutant mice are more susceptible to infection with Listeria monocytogenes, indicating that the Hck and Fgr gene products are involved in the immune response to intracellular pathogens.

\section{Results}

Generation of hck ${ }^{-1-}, \mathrm{fgr}^{-1-}$ and doubly

homozygous $\mathrm{hck}^{-1-}-\mathrm{fgr}^{-1-}$ mice

Gene disruptions were performed by introducing targeting constructs into the AB-1 ES cell line by electroporation, selecting for cells that survive "positive-negative" selection (Mansour et al. 1988), and screening for the desired recombinants by PCR and Southern blotting. Hck proteins are normally translated from two initiation sites, a CUG codon present in exon 1 and an AUG codon in exon 2, producing two proteins, $\mathrm{p} 59^{\text {hck }}$ and $\mathrm{p} 56^{\text {hck }}$, respectively (Lock et al. 1991). The hck gene was disrupted with a targeting construct that contains a neo expression cassette inserted at a restriction site 32 codons downstream from the AUG initiation methionine in exon 2 (Fig. 1A). The fgr gene was disrupted with two types of targeting constructs in which a neo expression cassette was inserted in the first coding exon (exon 2) to generate $f g r \Delta \mathrm{E} 2$ or used to replace a $2.0-\mathrm{kb}$ region of the gene, including exon 4 (fgr $\Delta \mathrm{E} 4$, Fig. 1B). The latter mutation would truncate proteins initiated at AUG codon 59 in the $3^{\prime}$ end of exon 2, a possible alternative start site for translation (C. Willman, pers. comm.).

Of $36 \mathrm{neo}^{+} / \mathrm{tk}^{-}$colonies $(56 \%)$ transfected with the

\section{B}
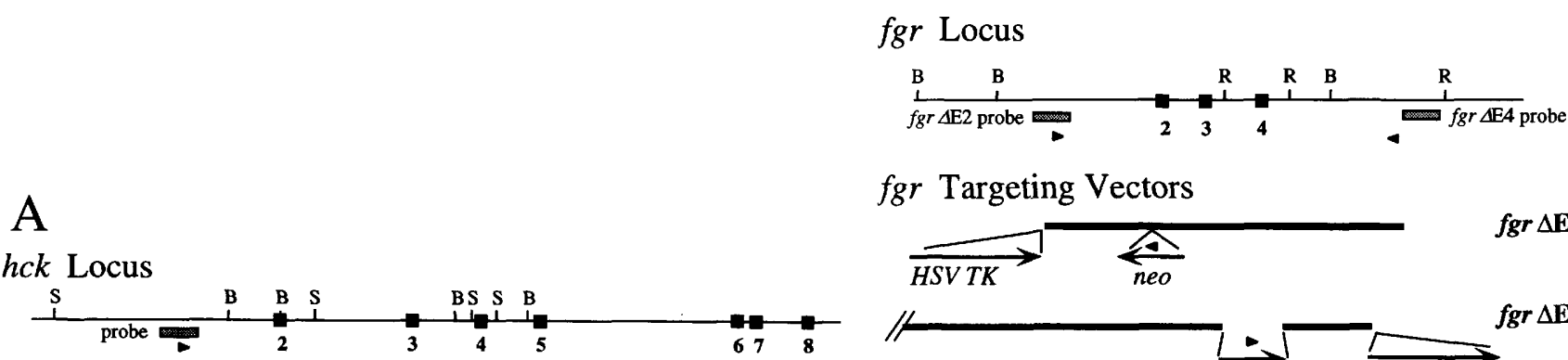

fgr Targeting Vectors

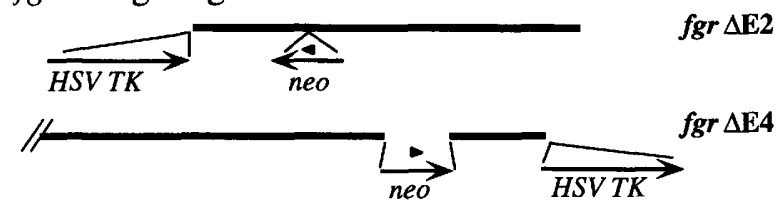

Expected BamHI Fragment Sizes

wt $7.5 \mathrm{~kb}$

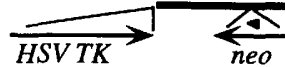

Expected SacI Fragment Sizes wt $6.0 \mathrm{~kb}$

mutant $7.5 \mathrm{~kb}$

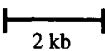

Expected EcoRI Fragment Sizes wt $3.5 \mathrm{~kb}$ mutant $5.0 \mathrm{~kb}$

Figure 1. Targeting $h c k$ and $f g r .(A, B) h c k$ and fgr loci and targeting vectors. Partial restriction maps of the murine hck and $f g r$ loci, the regions used as a targeting vectors, and the expected SacI, BamHI, and EcoRI fragments of the wild-type and mutant alleles are shown. The genomic regions used as a hybridization probes in ES cell and tail biopsy analyses are shown as a stippled boxes. Arrowheads indifgr $\Delta \mathrm{E} 4$ offspring cate PCR primers. Solid boxes with numbers indicate exons. Restriction sites are abbreviated as $\mathrm{B}(\mathrm{BamHI}) ; \mathrm{S}(\mathrm{SacI})$; and $\mathrm{R}(E c o \mathrm{RI})$. $(C)$ Tail DNA from 2 week-old offspring derived from heterozygous matings of hck, fgr $\Delta \mathrm{E} 2$, and fgr $\Delta \mathrm{E} 4$ animals was digested with SacI, $B a m H I$, or EcoRI, respectively, and hybridized with the probes indicated in $A$ and $B$. 
hck targeting vector, 20 scored positive by PCR. Similarly, 54 of $100 \mathrm{neo}^{+} / \mathrm{tk}^{-}$colonies $(54 \%)$ transfected with fgr $\Delta \mathrm{E} 2$ and 32 of $50 \mathrm{neo}^{+} / \mathrm{tk}^{-}$colonies $(64 \%)$ transfected with $f g r \Delta \mathrm{E} 4$ were positive in a PCR assay. These very high targeting frequencies were observed in several separate experiments. SacI digests of genomic DNA from all PCR-positive hck colonies demonstrated a novel 7.5$\mathrm{kb}$ fragment resulting from homologous insertion of the vector into hck. Genomic DNA from eight of each of the PCR-positive fgr $\triangle \mathrm{E} 2$ and fgr $\Delta \mathrm{E} 4$ colonies yielded a novel 9.0-kb BamHI fragment and 5.0-kb EcoRI fragment, respectively, that are diagnostic for the targeted allele. Hybridization with a neo probe confirmed the presence of a single copy of the replacement vector at each locus (data not shown).

ES cell clones successfully targeted with the $h c k$, fgr $\Delta \mathrm{E} 2$, and fgr $\Delta \mathrm{E} 4$ vectors were injected into C57BL/6J blastocysts, giving rise to three, two, and one germ-line chimeras, respectively. Animals heterozygous and homozygous for either the hck or fgr mutation display no overt phenotype, are fertile, and transmit each mutation at the expected Mendelian frequency (Fig. $1 \mathrm{C}$; Table 1 ). To generate mice that were deficient in both hck and $f g r$, we crossed $h \mathrm{ck}^{-1-}$ and fgr $\Delta \mathrm{E} 2$ animals to obtain $h_{c k}{ }^{+1-}-\mathrm{fgr}^{+1-}$ compound heterozygotes. The compound heterozygotes transmitted the two mutant genes

Table 1. Genotypes of offspring derived from hck, fgr, and hck-fgr heterozygous parents

\begin{tabular}{|c|c|c|c|}
\hline & \multicolumn{3}{|c|}{ hck $^{+1-} \times$ hck $^{+1-}$} \\
\hline & wild type & $h c k^{+1-}$ & $h c k^{-1-}$ \\
\hline & $52 / 203(26 \%)$ & $104 / 203(51 \%)$ & $47 / 203(23 \%)$ \\
\hline & & $f g r^{+1-} \times f g r^{+1-}$ & \\
\hline & wild type & $f g r^{+1-}$ & $f g r^{-1-}$ \\
\hline \multirow{4}{*}{$\begin{array}{l}f g r \Delta \mathrm{E} 2 \\
\text { fgr } \Delta \mathrm{E} 4\end{array}$} & $15 / 68 \quad(22 \%)$ & $38 / 68 \quad(56 \%)$ & $15 / 68 \quad(22 \%)$ \\
\hline & $28 / 114(25 \%)$ & $55 / 114(48 \%)$ & $31 / 114(27 \%)$ \\
\hline & $h c k^{+1}$ & $-f g r^{+1-} \times h c k^{+1}$ & $-f g r^{+1-}$ \\
\hline & $\mathrm{hck}^{+\prime+} \mathrm{fgr}^{+\prime+}$ & $h c k^{+/+} \mathrm{fgr}^{+1-}$ & $h_{c k}{ }^{+1+} \mathrm{fgr}^{-1-}$ \\
\hline \multirow{3}{*}{$\begin{array}{l}\text { Observed } \\
\text { Expected }\end{array}$} & $11 / 150(7 \%)$ & $17 / 150(11 \%)$ & $5 / 150(3 \%)$ \\
\hline & $(6 \%)$ & $(12 \%)$ & $(6 \%)$ \\
\hline & $h c k^{+1-} \mathrm{fgr}^{+1+}$ & $\mathrm{hck}^{+1-} \mathrm{fgr}^{+1-}$ & $h c k^{+1-} f g r^{-1-}$ \\
\hline \multirow{3}{*}{$\begin{array}{l}\text { Observed } \\
\text { Expected }\end{array}$} & $23 / 150(15 \%)$ & $39 / 150(26 \%)$ & $21 / 150(14 \%)$ \\
\hline & $(12 \%)$ & $(24 \%)$ & $(12 \%)$ \\
\hline & $h c k^{-1-} f g r^{+1+}$ & $h c k^{-1-} f g r^{+1-}$ & $h c k^{-1-} f g r^{-1-}$ \\
\hline Observed & $14 / 150(9 \%)$ & $12 / 150(8 \%)$ & $8 / 150(5 \%)$ \\
\hline Expected & $(6 \%)$ & $(12 \%)$ & $(6 \%)$ \\
\hline
\end{tabular}

Offspring from hck or $f g r$ heterozygous parents or hck-fgr compound heterozygous parents were genotyped as in Fig. 1C. The presence of the hck mutant allele can usually be confirmed phenotypically in 129Sv/C57BL6J hybrid animals because hck is closely linked to Agouti on chromosome 2. Among 350 offspring from $h c k$ heterozygous parents, we observed 4 recombinants between hck and Agouti. at the expected Mendelian frequency, so that one-sixteenth of their offspring were double homozygotes (Table 1). The doubly homozygous mice are also overtly normal and fertile, allowing establishment of $\mathrm{a} \mathrm{hck}^{-1-}$ $\mathrm{fgr}^{-1-}$ breeding colony.

To verify that each gene disruption creates a null mutation, we have examined hck and $f g r$ mRNAs in bone marrow-derived macrophages, and Hck and Fgr proteins in total bone marrow. Wild-type and hck ${ }^{+1-}$ cells contain a single 2.0-kb hck mRNA whose level is increased following activation with bacterial lipopolysaccharide (LPS) (Fig. 2A). LPS-activated $h_{c k}{ }^{-1}$ cells have a second 3.5-kb hck RNA, which hybridized with a neo probe (not shown), confirming that it is a hck-neo fusion transcript. In addition, we detected a low abundance hck-specific RNA that is slightly smaller than normal hck mRNA; this species is derived from splicing of exon 1 directly to exon 3 , as determined by reverse transcriptase (RT) PCR analysis (Fig. 2B). The shorter RNA lacks the initiator AUG codon from exon 2, as well as the neo insertion; in addition, the hck coding sequence from exon 3 is out of frame relative to the CUG translational start from exon 1. Thus, this RNA should be unable to encode functional Hck protein. To confirm the absence of normal Hck protein, we examined bone marrow by immunoblot analysis and immune complex kinase assays using antisera raised against the unique domain of Hck (see Materials and methods). Both p56 hck and p59 hck were detected in bone marrow from wild-type and $h c k^{+1-}$ animals but were absent in $h \mathrm{ck}^{-1-}$ samples (Fig. 3A). Likewise, no kinase activity was detectable in immunoprecipitates formed with the anti-Hck antisera and extracts of $\mathrm{hck}^{-1-}$ bone marrow (Fig. 3B).

Two fgr mRNAs are present in bone marrow-derived macrophages from wild-type mice, and both increase in abundance following activation of cells with LPS (Link et al. 1992). The two normal fgr mRNAs were absent in $\mathrm{fgr}^{-1-}$ cells, but two larger species were weakly detected with $f g r$ and neo probes (Fig. 2A). These putative $f g r-n e o$ fusion transcripts were confirmed by RT PCR analysis, using primers flanking the neo insertion. No aberrently spliced $f g r$ RNAs were found (Fig. 2B). p5 $5^{f g r}$ was detected in extracts of wild type and $\mathrm{fgr}^{+1-}$ bone marrow but not in extracts prepared from fgr $\Delta \mathrm{E} 2$ and fgr $\Delta \mathrm{E} 4$ animals, using a polyclonal anti-Fgr antiserum raised against the unique domain of the protein (Fig. 3A). No Fgr protein kinase activity was detected in $f g r^{-1}-$ bone marrow (Fig. 3B). Therefore, insertion of neo into the $f g r$ gene results in the production of low levels of readthrough transcripts that do not code for Fgr protein. Together, these results indicate that the disruptions in both $h c k$ and fgr result in loss of normal proteins and, hence, are very likely null mutations. Because the antiseras used in these experiments were raised against the unique amino-terminal regions of Hck and Fgr, we cannot exclude that carboxy-terminal fragments of each protein may be produced.

\section{Analysis of macrophage function in mutant mice}

Histological samples prepared from bone marrow, 
A

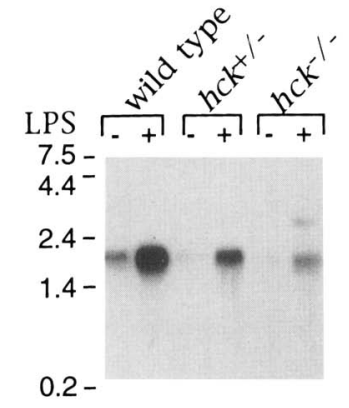

Probe: hckcDNA

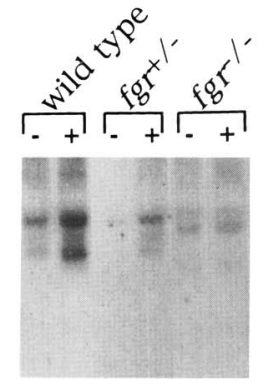

fgrcDNA

\section{B}
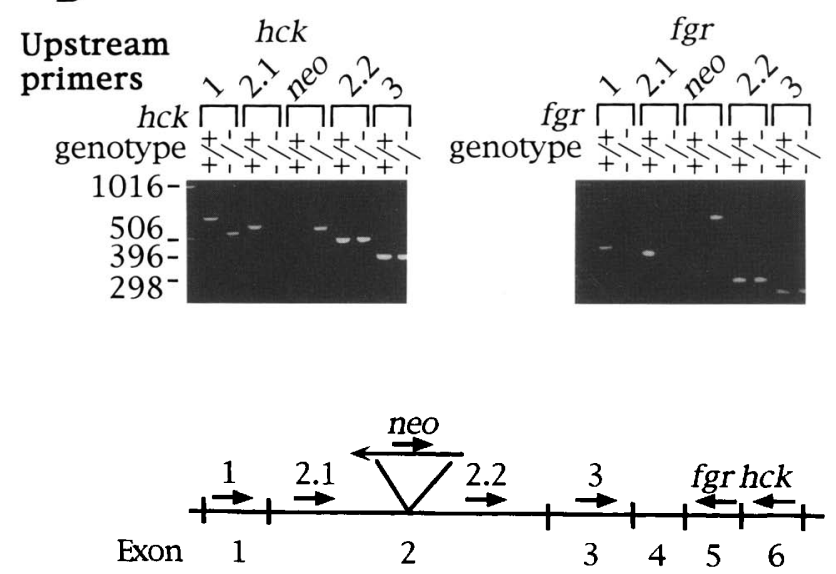

Figure 2. Hybridization and RT PCR Analyses of RNA from bone marrow macrophages cultured from $\mathrm{hck}^{-1-}$ and $\mathrm{Ygr}^{-1-}$ animals. $(A)$ Total RNA $(10 \mu \mathrm{g})$ from either resting $|-|$ or LPSactivated $(+)$ macrophages, isolated from animals with the indicated hck or fgr genotypes, was electrophoresed in formaldehyde gels and transferred to nylon sheets. Samples were hybridized with hck or fgr cDNA probes isolated from the unique 5 '-terminal regions of each cDNA clone. Sizes (kb) of RNA markers are shown. (B) RT PCR analysis of total RNA (l $\mu \mathrm{g})$ from LPS-activated macrophages was carried out using the primers shown in the schematic below (not to scale). For each mutant macrophage line, an upstream primer from exon 1 , two primers from exon 2 (flanking the neo insertion), one from within neo, and one from exon 3 were used with a downstream primer (from exon 6 for hck or exon 5 for $f g r$ ) in a PCR reaction. Note that amplification across the entire neo cassette does not occur, so that hck-neo or fgr-neo fusion transcripts do not give rise to the expected PCR products with exon 1 or upstream exon 2 primers. DNA markers (in nucleotides) are shown.

spleen, liver, thymus, lymph nodes, and peripheral blood cells from $h c k^{-1-}, f g r^{-1-}$, and $h c k^{-1-}-f g r^{-1-}$ animals were normal by conventional light microscopy. In addition, FACS analysis revealed no abnormalities in the numbers and percentages of cells within the myeloid and lymphoid compartments of each strain (Table 2). Mutant animals had normal numbers of resident peritoneal macrophages, as defined by cytological morphology and staining with the macrophage marker F4/80 (Austyn and Gordon 1981). Therefore, no deficiencies in hematopoietic development appear to occur in the absence of $h c k$, fgr, or both genes. In addition, no gross pathological or histological changes in nonhematopoietic organs were observed in any of the mutants.

We examined macrophages derived from $\mathrm{hck}^{-1-}$, $\mathrm{fgr}^{-1-}$, and $h \mathrm{ck}^{-1-}-\mathrm{fgr} \mathrm{I}^{-1-}$ animals to assess whether these mutations affected the functional properties of fully differentiated myeloid cells (Table 2). Of the numerous tests of in vitro function assayed, the single defect observed was impaired phagocytosis of latex beads by $h_{c k}{ }^{-1-}$ cells. Thioglycollate-elicited macrophages from $h c k^{-1-}$ mice have a reduced rate of ingestion of sIgG-coated latex beads compared with wild-type or $h_{c k}{ }^{+1-}$ cells (Fig. 4A). The reduced uptake varied from $\sim 20-60 \%$ of normal levels over multiple different experiments. Phagocytosis of latex beads is dependent on formation of active microtubules, as it can be blocked by incubation of cells at $4^{\circ} \mathrm{C}$ or by depolymerization of microtubules with cytochalasin B. Ingestion of BSA-coated beads was also reduced in hck ${ }^{-1}$ cells (not shown), indicating that the defect is not restricted to Fc $\gamma \mathrm{R}$-dependent phagocytosis. A similar impairment in latex bead phagocytosis was observed in thioglycollate-elicited $h k^{-1-}-f g r^{-1-}$ cells (Fig. 4B). Macrophages from $f g r^{-1-}$ mice take up latex beads normally; the defect seen in $h c k^{-1-}$ cells is not exacerbated by the fgr mutation. In contrast to latex bead phagocytosis, macrophages from wild-type, $h \mathrm{ck}^{-1-}, \mathrm{ggr}^{-1-}$, and $h \mathrm{ck}^{-{ }^{-}-}-\mathrm{fgr}^{-{ }^{-1}}$ animals rapidly ingested SIgG-SRBC, with equivalent levels of maximal uptake occurring after 20 min of incubation, indicating that the mutations do not affect Fc receptor signaling. We conclude that the Hck kinase plays an essential role in Fc $\gamma$ receptor-independent phagocytosis in thioglycollate-elicited macrophages. Although the Fgr kinase is associated with Fcy receptors in neutrophils and is activated following receptor cross-linking ( $\mathrm{Ha}-$ mada et al. 1993), our results demonstrate that this kinase is not required for Fc $\gamma$ receptor-dependent phagocytosis in macrophages.
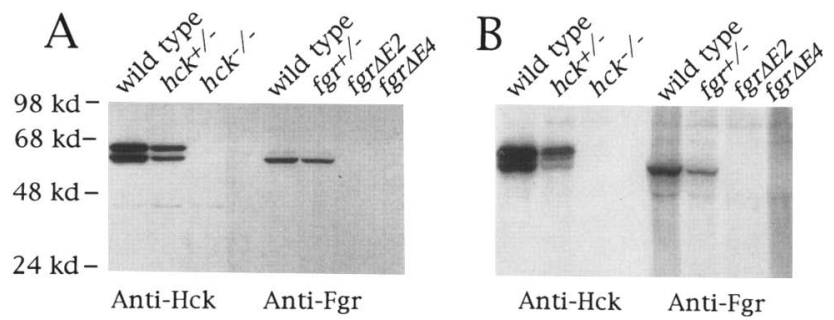

Figure 3. Analysis of Hck and Fgr proteins from mutant animals. (A) Whole-cell extracts were prepared from total bone marrow isolated from wild-type, heterozygous, and mutant animals. Each extract $(25 \mu \mathrm{g})$ was resolved on a $10 \%$ SDS-polyacrylamide gel, uansferred to nitrocellulose sheets, and immunoblotted with anti-Hck or anti-Fgr antisera prepared as described (see Materials and methods). Protein markers (in kD) are shown. $(B)$ Bone marrow protein extracts $(250 \mu \mathrm{g})$ were immunoprecipitated with anti-Hck or anti-Fgr antisera and incubated with $\left[\gamma^{32} \mathrm{P}\right] \mathrm{ATP}$ for $15 \mathrm{~min}$ at room temperature. Radiolabeled (autophosphorylated) bands were resolved on a 10\% SDS-polyacrylamide gel. 
Table 2. Summary of tested properties of macrophages from mutant mice

\begin{tabular}{|c|c|c|c|}
\hline Genotypes & $h c k^{-1-}$ & $f g r^{-1-}$ & $h c k^{-1-}-f g r^{-1-}$ \\
\hline $\begin{array}{l}\text { Histology, } \\
\text { hematopoietic cell } \\
\text { compartments }^{\mathrm{a}}\end{array}$ & $\mathrm{nl}$ & $\mathrm{nl}$ & $\mathrm{nl}$ \\
\hline $\begin{array}{l}\text { Uptake of IgG-coated } \\
\text { or BSA-coated latex } \\
\text { beads }\end{array}$ & reduced & $\mathrm{nl}$ & reduced \\
\hline $\begin{array}{l}\text { Uptake of } \\
\text { IgG-SRBCs }\end{array}$ & $\mathrm{nl}$ & $\mathrm{nl}$ & $\mathrm{nl}$ \\
\hline $\begin{array}{l}\text { Production of } \\
\text { cytokines and } \mathrm{NO}_{2} \\
\text { in response to LPS, } \\
\text { heat-killed Listeria, } \\
\text { Zymosan }\end{array}$ & $\mathrm{nl}$ & $\mathrm{nl}$ & $\mathrm{nl}$ \\
\hline $\begin{array}{l}\text { PMA-triggered } \\
\text { respiratory burst }\end{array}$ & $\mathrm{nl}$ & $\mathrm{nl}$ & $\mathrm{nl}$ \\
\hline $\begin{array}{l}\text { IFN- } \boldsymbol{\gamma} \text {-induced } \\
\text { expression of Ia } \\
\text { antigens }^{\mathrm{f}}\end{array}$ & & & $\mathrm{nl}$ \\
\hline $\begin{array}{l}\text { Tumor cell } \\
\text { cytotoxicity }\end{array}$ & & & $\mathrm{nl}$ \\
\hline $\begin{array}{l}\text { Formation of } \\
\text { peritoneal exudate }\end{array}$ & $\mathrm{nl}$ & $\mathrm{nl}$ & $\mathrm{nl}$ \\
\hline $\begin{array}{l}\text { Tyrosine } \\
\text { phosphorylation } \\
\text { responses }^{i}\end{array}$ & $\mathrm{nl}$ & $\mathrm{nl}$ & $\mathrm{nl}$ \\
\hline $\begin{array}{l}\text { Listeria killing in } \\
\text { vitro }^{\mathrm{j}}\end{array}$ & & & $\mathrm{nl}$ \\
\hline $\begin{array}{l}\text { Listeria antigen } \\
\text { presentation }^{\mathrm{k}}\end{array}$ & & & $\mathrm{nl}$ \\
\hline
\end{tabular}

All tests were carried out with both thioglycollate-elicited and bone marrow-derived macrophages. (nl) Normal.

${ }^{a}$ Assayed by FACS analysis of bone marrow, spleen, thymus, and resident peritoneal cells with myeloid markers Mac-l, and Gr-1; lymphoid markers CD-3, CD-4, CD-8, B220, and sIgM; and monocoyte/macrophage marker $\mathrm{F} 4 / 80$.

${ }^{b}$ Assayed by fluoremetry using fluorescent latex beads.

${ }^{c}$ Assayed by indirect immunofluorescence.

${ }^{\mathrm{d}}$ Cell-free supernatants from macrophages were assayed at 16 $\mathrm{hr}$ following addition of LPS, heat-killed Listeria, or Zymosan for TNF- $\alpha$, IL- $1 \alpha$, and IL- 6 by ELISA and $\mathrm{NO}_{2}{ }^{-}$by addition of Greiss reagent. Induction of mRNAs encoding TNF- $\alpha$, TGF- $\beta$, IL-10, IL-12, MIP-1 $\alpha$, and inducible nitric oxygen synthetase were measured by RT-PCR.

${ }^{\mathrm{e}}$ Assayed by the superoxide dismutase-inhibitable reduction of cytochrome $c$.

${ }^{\mathrm{f}}$ Macrophages were cultured for $16 \mathrm{hr}$ in $100 \mu / \mathrm{ml}$ IFN- $\gamma$ and assessed for Ia expression by FACS analysis.

${ }^{\mathrm{g}}$ Assayed by $48 \cdot \mathrm{hr}{ }^{51} \mathrm{Cr}-$ releasing using P815 and YAC-1 cells as targets.

h Assayed by cell counts and morphology at varying times following injection of thioglycollate.

i Total cellular protein phosphotyrosine assayed by Western blot of whole cell extracts made $15 \mathrm{~min}$ following stimulation with LPS, phorbol myristate, GM-CSF, anti-Mac-1 or antiFc $\gamma$ R.

${ }^{j}$ LPS- and TNF- $\alpha$-activated macrophages were cultured with live Listeria, and bacteriacidal activity was measured.

${ }^{\mathrm{k}}$ Macrophages were cultured with heat-killed Listeria and used as targets in CTL assay using splenocytes from Listeria-infected animals.
Because the Src kinases have been implicated in a wide variety of cell signaling pathways, we examined total cellular phosphotyrosine levels in resident peritoneal macrophages, and bone marrow-derived macrophages in response to LPS, phorbol myristate, Zymosan, granulocyte-macrophage colony-stimulating factor (GM-CSF), Mac-1 (integrin), and Fc $\gamma \mathrm{R}$ cross-linking. Cells from wild-type and mutant mice were challenged with each of the above agents for $15 \mathrm{~min}$, and phosphotyrosine-containing proteins were detected by immunoblotting. No significant deficits in tyrosine phosphorylation were observed in macrophages from $h \mathrm{ck}^{-1-}, f g \mathrm{r}^{-1-}$, and $h_{c k}{ }^{-1-} \mathrm{fgr}^{-1-}$ mice.

Because the fgr gene is expressed in natural killer (NK) and IL-2 stimulated killer (LAK) cells, we tested the ability of these cells from mutant mice to lyse a variety of tumor cell targets (Ryan et al. 1991). The ability of NK and LAK cells from wild type, $h c k^{-1-}$ and $f g r^{-1-}$ mice to lyse four different tumor cell lines was equivalent. All cell types showed augmented killing when targets were incubated with anti- $\mathrm{H} 2 \mathrm{mAbs}$, indicating no impairment of ADCC in these cells.

\section{Analysis of other src kinases in $\mathrm{hck}^{-1-}$ and $\mathrm{fgr}^{-1-}$ mice}

The lack of defects in most of the above assays could be attributable to a compensatory increase in the activity of other Src family kinases in response to the loss of Hck or Fgr. To look for modulation of Src kinases in mutant animals we examined Hck, Fgr, Lyn, and Src kinase and protein levels in bone marrow-derived macrophages from $\mathrm{hck}^{-1-}$ and $\mathrm{fgr}^{-1-}$ mice. The amount of immunoprecipitable Lyn kinase activity (judged by autophosphorylation) was increased in $h c k^{-1-}$ macrophages compared with wild-type cells (Fig. 5A). No significant differences were seen in Lyn protein levels in hck ${ }^{-1-}$ and wild-type cells, by performing immunoblots with the same cell extracts (Fig. 5B). We conclude that the specific kinase activity of Lyn is increased in $h c k^{-1-}$ macrophages. Quantitative analysis of three independent experiments indicated that Lyn kinase activity is increased two- to threefold in both resting and activated $h_{c k}{ }^{-1}$ macrophages (Fig. 5C). In contrast, we observed no modulation of Fgr or Src kinase activity or protein levels in $\mathrm{hck}^{-1-}$ macrophages. Likewise, no modulation of Hck, Lyn, or Src kinase activities or protein levels were seen in resting, primed, or activated $f g r^{-1-}$ macrophages (data not shown).

\section{Immune response to infectious challenge in mutant mice}

To determine whether the mutant animals have defects in resistance to microbial disease, we infected mice with the protozoan Leishmania major and the bacterial pathogen $L$. monocytogenes. The cell membranes of the intracellular amastigote of Leishmania are inherently resistant to the low levels of reactive oxygen and nitrogen intermediates produced by resting macrophages (Hand- 

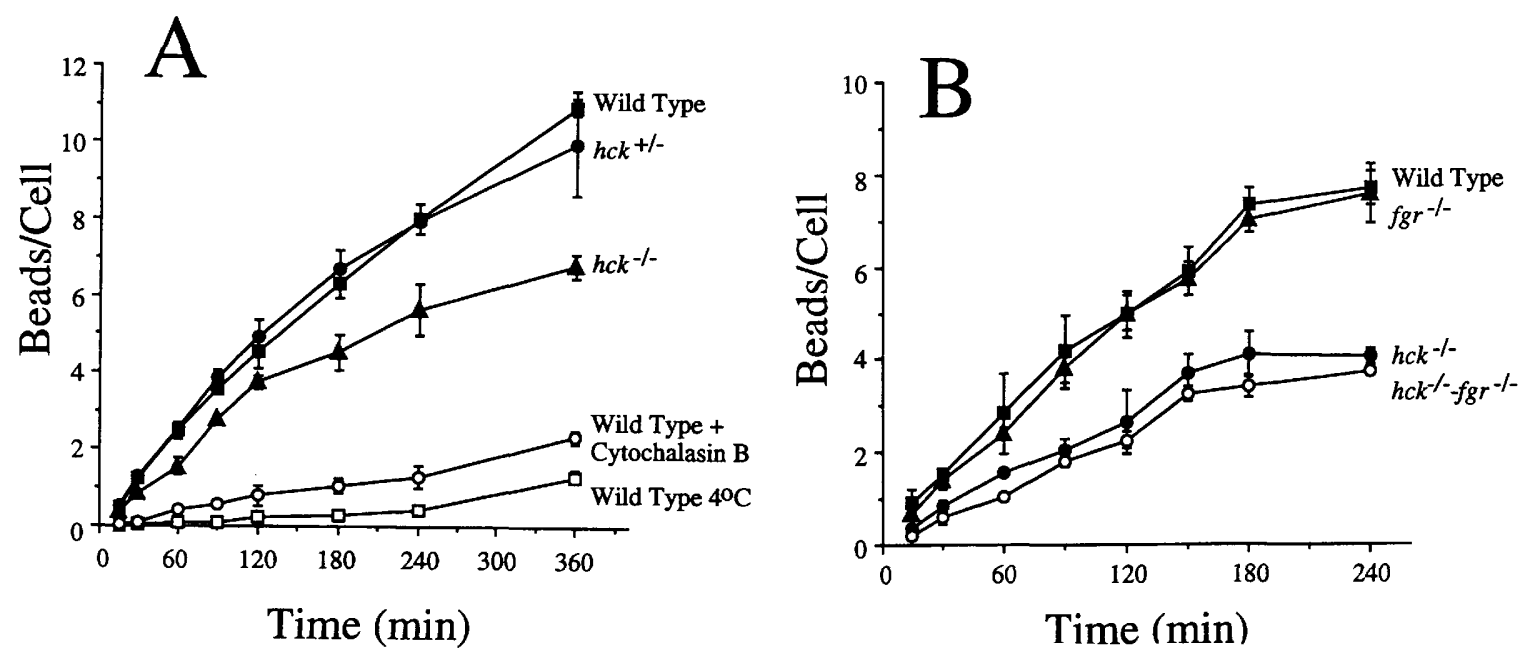

Figure 4. Uptake of fluorescent IgG-Coated latex beads by thioglycollate-elicited macrophages. $(A)$ Latex bead uptake was assayed by incubating cells with fluorescent beads (Oda and Maida 1986). Thioglycollate-elicited macrophages $\left(5 \times 10^{5}\right.$ cells) from wild-type, $h \mathrm{ck}^{+1-}$, and $\mathrm{hck}^{-1-}$ mice were cultured in 24 -well dishes for $16 \mathrm{hr}$ in $\alpha$-MEM/10\% FCS, then incubated with fluorescent IgG latex beads at a ratio of 25 beads per cell and assayed as described in Materials and methods. Cytochalasin B was added to some wild-type cultures to a final concentration of $20 \mu \mathrm{M} 1 / 2 \mathrm{hr}$ prior to addition of beads. Others were cooled to $4^{\circ} \mathrm{C} 1 \mathrm{hr}$ prior to addition of beads. Each data point represents three separate determinations \pm the standard error of the mean. $(B)$ Latex bead uptake as above using cells isolated from wild-type, $f g r^{-1-}, h c k^{\prime-}$ and $h c k^{-1-}-f g r^{-1-}$ mutant animals.

man et al. 1986). Listeria is a Gram-positive bacterium that can survive intracellularly in nonactivated macrophages by escaping from the phagosome into the cytoplasm of the cell (Tilney and Portnoy 1989; Bancroft et al. 1991). Clearance of these infections is dependent on macrophage activation mediated by the production of cytokines from macrophages, $\mathrm{T}_{\mathrm{h}} 1$ and NK cells (Scott 1993).

Wild-type and $h c k^{-1-}-f g r^{-1-}$ doubly homozygous mice were infected with $L$. major via foot pad injection, and foot swelling was monitored weekly for 6 weeks. All animals were able to resolve the infection. These mice demonstrated normal delayed-type hypersensitivity reactions to skin challenge with Leishmania antigens, as well as the presence of circulating antibodies to Leishmania as demonstrated by immunoblot. Hence, $h c k^{-1-}$ $\mathrm{fgr}^{-1-}$ mice are able to mount both humoral and cellmediated immunity to chronic Leishmania infection.

Wild-type, $h \mathrm{ck}^{-1-}, \mathrm{fgr}^{-1-}$, and $h \mathrm{ck}^{-1-}-\mathrm{fgr}^{-1-}$ mice (both inbred 129/Sv and hybrid animals) were challenged with Listeria by intraperitoneal injection. There was very little mortality in infected wild-type, $h_{c k^{-1-}}$, or $\mathrm{fgr}^{-1-}$ mice, and there were no significant differences in numbers of splenic or peritoneal Listeria colony-forming units among the different animals at several time points. In contrast, the ability of $h \mathrm{ck}^{-1-}-\mathrm{fgr}^{-1-}$ double homozygotes to resolve this infection is impaired (Fig. 6A and data not shown). Within 2 days following infection, although wild-type mice appeared healthy, the doubly mutant animals appeared very ill (roughed fur, decreased mobility, conjunctival exudates, weight loss). The hck $/^{-}--\mathrm{fgr}^{-/-}$mice had 100- to 1000 -fold more Listeria in spleens and peritoneal cells after 9 days of infection. With an inoculum of $10^{4}$ organisms, 4 of 24 $h c k^{-1-}-f g r^{-1-}$ animals died over the 9 day course of infection, whereas all wild-type and singly mutant animals survived. When the Listeria inoculum was increased to $4 \times 10^{4} \mathrm{cfu}$, and animals were monitored for mortality alone, $>70 \%$ of the $h_{c k}{ }^{-1-}-f g r^{-1-}$ animals died within 10 days following injection; fewer than $10 \%$ of the wild-type animals succumbed to the infection (Fig. $6 \mathrm{~B})$. Thus, neither $h c k$ nor $f g r$ alone is essential to mount an effective immune response to Listeria. However, deficiency of both kinases produces a marked defect in the cell-mediated immune response to this organism.

\section{Discussion}

We have used gene targeting methods to disrupt two src family genes, hck and fgr, which are coexpressed in the myelomonocytic lineage. Phagocytosis by macrophages from hck-deficient mice is impaired, but no other defects were observed, and the $f g r$-deficient animals appeared normal by all tested criteria. Doubly homozygous $h c k^{-1-}-f g r^{-1-}$ macrophages had no supplemental defects. However, doubly homozygous, hck ${ }^{-1-}-f g r^{-1-}$ animals are more susceptible to infection by $L$. monocytogenes than are wild-type or singly mutant mice, indicating that these genes cooperate to establish an immune defense against this (and perhaps other) intracellular pathogens.

\section{Targeting of hck and fgr}

At least two features of targeting the hck and fgr loci proved to be unusual. First, the efficiency of homologous recombination was unusually high, even when the targeting vector (for $h c k$ ) was prepared with DNA from a 

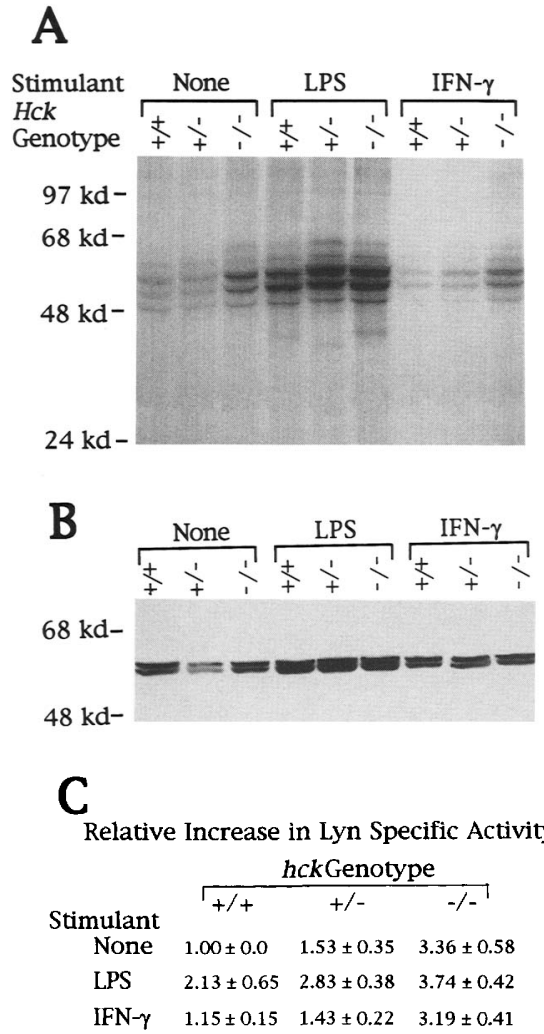

Figure 5. Measurement of lyn kinase activity and protein levels in $h \mathrm{ck}^{-1-}$ macrophages. (A) Protein extracts $(250 \mu \mathrm{g})$ from resting, LPS-activated, and INF- $\gamma$-treated bone marrow macrophages isolated from wild-type, hck ${ }^{+/-}$or $h c k^{-1-}$ mice were immunoprecipitated with anti-Lyn antisera (see Materials and methods). Immunoprecipitates were incubated with $\left[\gamma^{32} \mathrm{P}\right]$ ATP for $15 \mathrm{~min}$ at room temperature, and phosphorylated proteins were resolved on a $10 \%$ SDS-polyacrylamide gel. $(B)$ Twentyfive micrograms of the above extracts were electrophoresed on $10 \%$ SDS-polyacrylamide gels, transferred to nitrocellulose, and immunoblotted with the anti-Lyn antisera. $(C)$ Lyn specific activity was quantitated by dividing the total Lyn kinase activity by the protein level for each sample. Results were normalized to resting macrophages. Data represents mean \pm S.D. of three independent experiments.

mouse strain that differed from the source of ES cells /te Riele et al. 1992). Second, insertion of a neo gene within a coding exon of hck resulted in production of an aberrantly spliced transcript that lacks sequences from the interrupted exon (Fig. 2). This effect on RNA splicing has not been reported previously in ES cell gene targeting experiments and is consistent with an exon scanning model for RNA splicing (Niwa et al. 1992). Although exon skipping of this type does not appear to allow synthesis of a functional hck gene product (Fig. 3), it could in principle produce proteins lacking only those sequences encoded by the disrupted exon, thereby undermining the intention to create a null allele. Such observations emphasize the importance of direct measurement of the products of targeted loci.
Effects of hck and fgr deficiencies on macrophage functions and hematopoiesis

We have tested macrophages from the mutant mice for many properties that can be measured in vitro (Table 2), but the only deficiency observed was impaired phagocytosis by Hck-deficient cells. This defect is probably not attributable to alterations in Fc $\gamma \mathrm{R}$-mediated phagocytosis, as $h \mathrm{ck}^{-1-}$ cells take up sIgG-SRBC phagocytosis normally, signal through $\mathrm{Fc} \gamma \mathrm{R}$ (as judged by tyrosine phosphorylation), and are deficient in phagocytosis of BSA-coated latex beads. Instead, some other intracellular event, such as phagosome membrane trafficking, may be impaired in $h_{c k}{ }^{-1-}$ macrophages; similar explanations have been proposed for the inhibitory effects of transforming growth factor- $\beta$ (TGF- $\beta$ ) on phagocytosis and the generation of oxidants (Gresham et al. 1991). Alone, the diminished phagocytosis of $\mathrm{hck}^{-1-}$ macrophages does not appear to result in a major physiologic defect, as $h \mathrm{ck}^{-1}$ - mice are able to resist infection by $L$. monocytogenes and L. major. However, in concert with the fgr mutation, the phagocytic defect may be a contributory factor in the sensitivity of $h_{c k}^{-1-}-f g r^{-1-}$ mice to Listeria (see below).

The lack of novel phenotypes in macrophages cultured from doubly mutant mice may be explained in several ways: (1) Other src family kinases may compensate for the hck and fgr mutations; (2) hck and fgr may serve nonoverlapping functions in macrophages; (3) in vitro assays of macrophage function may not detect subtle deficiencies that are significant in vivo. Our observation that Lyn kinase activity is elevated in hck ${ }^{\prime-}$ cells suggests that modulation of Lyn activity may relieve functional impairments threatened by a loss of Hck. The degree of increase in Lyn kinase activity in $h_{c k}^{-1-}$ macrophages is moderate, approximately twofold. This is similar to the normal physiologic responses of Src kinases, as observed when Lck is activated following CD4 crosslinking, when Lyn is activated after FceR crosslinking, or when Src is activated during mitosis (Bolen et al. 1992; Bagrodia et al. 1993). A larger (10-fold) increase in Src kinase activity (e.g., that achieved by mutating Tyr-527; Piwnica-Worms et al. 1987) will render the kinase oncogenic. The increased activity of Lyn is likely a result of under-phosphorylation of its regulatory carboxy-terminal tyrosine, possibly as a result of reduced Csk kinase activity or increased phosphatase activity (Cooper and Howell 1993). The modulation of Lyn kinase activity in $h c k^{-1-}$ cells suggests that these kinases may have related functions; however, a direct demonstration that Lyn and Hck serve redundant functions will require generation of $h c k^{-1-}-\mathrm{yn}^{-1-}$ double homozygous mice.

Several pieces of evidence support the model that $h c k$ and $f g r$ have nonoverlapping functions in macrophages. First, we have found that Hck and Fgr have different subcellular locations in macrophages; Hck is found exclusively in the cytoplasm, whereas Fgr is found in the nucleus and cytoplasm (data not shown). Second, the roles of Hck, Fgr, and Lyn in monocyte and macrophage 

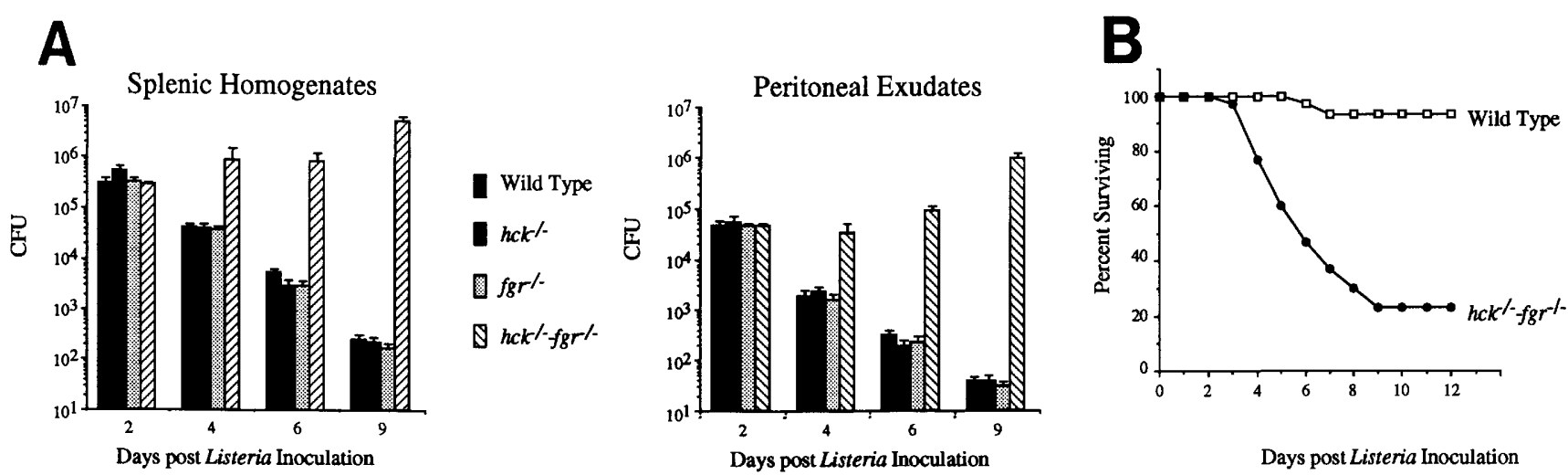

Figure 6. hck-fgr double homozygotes are susceptible to L. monoctyogenes. (A) Wild-type, $h c k^{-1-}, f g r^{-1-}$, and $h c k^{-1-}-f g r^{-1-}$ mice were inoculated with $10^{4} \mathrm{cfu}$ of Listeria by intraperitoneal injection and sacrificed on the days indicated. Bacterial cfu was measured in homogenates of spleen (left) and peritoneal (right) exudates. Each bar presents average cfu from five animals \pm the standard error of the mean. Four $h c k^{-1-}-f g r^{-1-}$ mice died during the experiment and are not included in the analysis. $(B)$ Thirty-five wild-type or $h c k^{-1-}-f g r^{-1-}$ mutant animals were inoculated with $4 \times 10^{4} \mathrm{cfu}$ of Listeria and observed for mortality. The percentage of original mice surviving at each day is shown.

activation is suggested by the observation that the activity and tyrosine phosphorylation of these kinases increases rapidly after stimulation of cells with LPS (Stefanova et al. 1993|. However, Hck and Lyn are modulated within 1 min of stimulation while changes in Fgr occur after 15 min of treatment with LPS. The differential response of Hck and Lyn compared with Fgr suggests different roles for these kinases in the LPS response.

Because both hck and fgr are expressed late in myeloid development, these genes might be predicted to play no major role in hematopoiesis. Consistent with this prediction, $h c k^{-1-}, f g r^{-1-}$, and $h c k^{-1-}-f g r^{-1-}$ mice display normal hematopoietic development, as judged by histologic examination and cell-surface antibody staining. However, we have recently observed that animals lacking both hck and src have hematopoietic defects characterized by anemia, leukopenia, and an accumulation of immature cells in the spleen, suggesting a block in hematopoiesis (C.A. Lowell and H.E. Varmus, unpubl.). Therefore, we favor the argument that the developmental roles of $h c k$ and $f g r$ are fulfilled by other genes, such as src and lyn, coexpressed in hematopoietic cells.

\section{Natural immunity in $\mathrm{hck}^{-/-}-\mathrm{fgr}^{-1-}$ mice}

In contrast to results obtained from of in vitro assays of macrophage function, synergy between hck and fgr was observed in vivo as $h c k^{-1}-f g r^{-1}-$ animals are more susceptible than wild-type, $h \mathrm{ck}^{-1-}$, or $f g r^{-1-}$ mice to $L$. monocytogenes. The mechanism of reduced defense is, however, not known. Recently, many of the cellular responses involved in natural resistance to Listeria have been defined. Production of TNF- $\alpha, \mathrm{IL}-10$, and IL-12 by Listeria-infected macrophages influences the development of $T_{h} 1$ or $T_{h} 2$ subtype cells, which produce gamma interferon (IFN- $\gamma$ ) or IL-4, respectively (Scott 1993). These cytokines have opposing effects: IFN- $\gamma$ primes macrophages to destroy the organisms, whereas IL-4 sup- presses macrophage activation, allowing bacterial proliteration. Blocking the IFN- $\gamma$ response, either by injection of neutralizing anti-IFN- $\gamma \mathrm{mAb}$ or by targeted disruption of the IFN- $\gamma$ receptor, renders mice susceptible to Listeria (Buchmeier and Schreiber 1985; Huang et al. 1993). $h c k^{-1-}-f g r^{-1-}$ macrophages respond normally to heatkilled Listeria and IFN- $\gamma$ in vitro as judged by induction of these cytokine RNAs and production of reactive nitrogen intermediates (Table 2). Splenocytes from infected mutant animals also respond normally. These results are surprising in light of the fact that production of $\mathrm{NO} \cdot$ has been claimed to be a major mediator of natural resistance to Listeria, animals treated with aminoguanidine (an inhibitor of nitric oxide synthetase) are markedly susceptible to Listeria (Beckerman et al. 1993). Therefore, our mice are defective in other, as yet undefined, components of natural immunity to Listeria. The susceptibility of $h \mathrm{ck}^{-1-}-\mathrm{fgr} \mathrm{r}^{-1-}$ mice to Listeria could be the result of the cumulative affects of each mutation on different cellular immune functions-for example, the reduced nonreceptor phagocytosis seen in hck ${ }^{-1-}$ cells, compounded with an alteration in chemotaxis of monocytes to the spleen or reduced adhesion of cells to capillary endothelium. Such an explanation would predict that the biochemical mechanism for the genetic interaction between $h c k$ and $f g r$ is quite indirect. The specificity of the altered natural immune response of $h \mathrm{ck}^{-1-}-\mathrm{fgr}^{-1-}$ animals needs to be evaluated further by determining the susceptibility of these mice to infection by a number of bacterial, viral, and protozoan organisms.

\section{src family genetics}

Our observation that both hck and fgr are required for resistance to Listeria infection is the first direct demonstration of genetic synergy within the src gene family. Genetic interactions between other src family members is probably quite common. For example, animals ho- 
mozygous for hck and src mutations exhibit hematopoietic deficiencies that do not occur in singly mutant mice, implying that $h c k$ and src have complementary roles in blood cell ontogeny (C.A. Lowell and H.E. Varmus, unpubl.). Overlapping function among the Src family members Fyn, Yes, and Src is also suggested by the observation that animals deficient for two of these kinases exhibit novel and severe phenotypes not seen in the singly deficient mice (P. Stein and P. Soriano, unpubl.). To explore the full range of physiological functions performed by members of the src gene family, it will be important to mutate the remaining members of the $s r c$ gene family, especially those with patterns of expression that overlap $h c k$ and $f g r$, and to make different combinations of $s r c$ family kinase-deficient mice.

\section{Materials and methods}

\section{Derivation of hck and fgr mice}

The hck targeting vector consisted of a herpes simplex virus thymidine kinase (HSV TK) expression cassette (pgkTKpgkpA), a short arm of $1.8 \mathrm{~kb}$ from the $5^{\prime}$ region of mouse hck, a pgkneo-pgkpA expression cassette, and a long arm of $12 \mathrm{~kb}$ of hck genomic sequence. The BamHI site in exon 2 was mutated to encode stop codons in all three reading frames followed by a Sall site. The neo cassette was inserted into the Sall site in the opposite transcriptional orientation from hck. The vector was linearized at a unique EcoRI site in the plasmid polylinker located $3^{\prime}$ to the long arm of hck genomic sequence. The construct was made from a hck clone isolated from a BALB/c library (Ziegler et al. 1987); hence, it is nonisogenic relative to the AB-1 ES cells derived from strain 129 . The fgr $\Delta \mathrm{E} 2$ vector contains a pgkTK-pgkpA gene, $2.3 \mathrm{~kb}$ of $f g r$, a pol2Sneo-bpA (Soriano et al. 1991) expression cassette, and a long arm of $6.0 \mathrm{~kb}$ of fgr genomic sequence. The neo cassette was inserted into an $X$ hol site that was generated by deleting 66 nucleotides of exon 2 by site-directed mutagensis. The fgr $\Delta \mathrm{E} 2$ vector was linearized at a unique SalI site in the plasmid polylinker downstream from the long arm of homology. The fgr $\Delta \mathrm{E} 4$ vector includes $9.0 \mathrm{~kb}$ of $f g r$, a pgkneo-bpA expression cassette, a short arm of $2.0 \mathrm{~kb}$ of fgr, and a pgkTK-pgkpA gene. The neo cassette replaces a $2-\mathrm{kb}$ EcoRI fragment that includes all of exon 4, which encodes amino acids 98-133-most of the $\mathrm{SH} 3$ domain of Fgr protein (King and Cole 1990). The fgr $\Delta \mathrm{E} 4$ vector was linearized at a unique $X$ hol site in the 5 ' plasmid polylinker upstream from the long homology arm. The fgr targeting constructs were made from a fgr genomic clone isolated from a $129 / \mathrm{Sv}$ library.

Vectors were introduced into AB-1 ES cells by electroporation as described previously (Soriano et al. 1991), selected in 300 $\mu \mathrm{g} / \mathrm{ml}$ (total powder) of G418, and $0.2 \mu \mathrm{M}$ FIAU for 10 days. Selection against HSV TK reduced the number of neo ${ }^{+}$colonies by two- to fivefold in multiple experiments. Surviving colonies were screened by PCR as described (Soriano et al. 1991) using $10 \mathrm{nM}$ primers; amplification was for 40 cycles $(30 \mathrm{sec}$ at $93^{\circ} \mathrm{C}, 2 \mathrm{~min}$ at $60^{\circ} \mathrm{C}, 2 \mathrm{~min}$ at $65^{\circ} \mathrm{C}$. Primers were derived from hck or $f g r$ genomic sequences adjacent to the short arm of homology in each vector (for $h c k, 5^{\prime}$-GGACCTAGGGATTCTCTGCTGCATGC-3'; for fgr $\triangle \mathrm{E} 2,5^{\prime}$-GTGAGTGTGCCAAGCTGAGAAGCATCC-3'; for fgr $\triangle \mathrm{E} 4$, 5'-CCGAATCCATGGACCTCCACTTGTTCC-3') and from the 5' end of the neo gene (5'-CCAGTCATAGCCGAATAGCCTCTCCACC-3'). PCR-positive clones were expanded, and homologous insertion of the targeting vectors was confirmed by blot hybridization with probes isolated from flanking genomic sequences not present in the targeting vectors (for hck, a 350-bp EcoRI-KpnI 5 '-flanking fragment; for fgr $\Delta \mathrm{E} 2$, a 500-bp BamHI-EcoRV 5'flanking fragment; for fgr $\Delta \mathrm{E} 4$, a 1-kb EcoRI-EcoRV 3'-flanking probe). Expanded ES clones were confirmed to contain a single replacement vector inserted into hck or fgr by DNA analysis, using multiple digests and hybridization with both $5^{\prime}$ - and $3^{\prime}$. flanking probes. Tissue culture manipulations and blastocyst injections were performed as described (Soriano et al. 1991). Germ-line chimeras were crossed with $\mathrm{C} 57 \mathrm{BL} / 6 \mathrm{~J}$ females to produce hybrid animals, and $F_{1}$ offspring from this cross were backcrossed one generation to $\mathrm{C} 57 \mathrm{BL} / 6 \mathrm{~J}$ to establish mutant strains for subsequent analysis. Two independent murine lines containing the hck mutation and one each with the fgr $\Delta \mathrm{E} 2$ and fgr $\Delta \mathrm{E} 4$ mutations were established from independent chimeras. No phenotypic differences were seen between the two hck lines or between the fgr $\Delta \mathrm{E} 2$ or fgr $\Delta \mathrm{E} 4$ lines. The fgr $\Delta \mathrm{E} 2$ mice were used for the majority of macrophage functional assays. Chimeras were also bred to $129 / \mathrm{Sv}$ females to maintain the $h c k$ and $f g r$ mutations on an inbred genetic background.

\section{Cell culture}

Bone marrow-derived macrophages were obtained from precursor cells as described (Yi and Willman 1989) except that monocytes were cultured in $20 \%$ murine L-cell conditioned media. After plating of nonadherent monocyte precursors, cells were cultured for 6-8 days and then used for phagoctyosis and activation assays. Thioglycollate-elicited macrophages were prepared by intraperitoneal injection of $2 \mathrm{ml}$ of aged (>6 weeks) $2 \%$ thioglycollate broth (GIBCO), followed by flushing the peritoneal cavity with PBS $/ 0.2 \%$ BSA 4 days later. Thioglycollateelicited cells were cultured in $\alpha$-MEM $+10 \%$ FCS for $4 \mathrm{hr}$, nonadherent cells were removed, and adherent cells were cultured for $1-3$ days.

\section{RNA analysis}

Total RNA was prepared from bone marrow-derived macrophages (Chomczynski and Sacchi 1987), electrophoresed on 1\% formaldehyde gels, and transferred to nylon membranes (Sambrook et al. 1989). hck mRNA was detected by hybridization with a 515-bp EcoRI-HincII fragment from the $5^{\prime}$ end of the hck cDNA clone (Holtzman et al. 1987), which encodes the amino-terminal unique domain and a portion of the $\mathrm{SH} 3$ region. fgr mRNA was detected by with a 750-bp SpeI-ApaI from the $5^{\prime}$ end to the fgr cDNA (King and Cole 1990), which encodes the amino-terminal unique domain, $\mathrm{SH} 3$ and a portion of the $\mathrm{SH} 2$ region of Fgr. cDNA was made for RT PCR analysis using $1 \mu \mathrm{g}$ of total RNA and $40 \mathrm{ng}$ of random hexamers under standard reaction conditions in a volume of $20 \mu \mathrm{l}$. The reaction was carried out for $1 \mathrm{hr}$ at $37^{\circ} \mathrm{C}$, terminated by heating to $65^{\circ} \mathrm{C}$ for $10 \mathrm{~min}$, and diluted to $200 \mu \mathrm{l}$. Five-microliter portions of the cDNAs were used in PCR reactions done under conditions described above. The following PCR primers were used: hck exon 1, 5'-GGTCGGTCTAGCTGCGAGGATC-3'; hck exon 2.1, 5' -CGAGGTTCCTCCGAGATGGAAGC$3^{\prime}$; hck exon 2.2, 5'-CGTCCAGCAAGCTGGGACCA-3'; hck exon 3, 5'-GCTATTCACCGTGAAGACCTCAGC-3'; hck exon 6, 5' -TTGTAGTGGAGCAGCAGTTCCTGC-3'; fgr exon 1, 5'-GTCCTATTGACCCAGGAGTAGG-3'; fgr exon 2.1, $5^{\prime}$-GGAATGGGCTGTGTGTTCTGCA-3' ${ }^{\prime}$, $g r$ exon $2.2,5^{\prime}$-CAACACTGGCAACATCGAGAAGC-3', fgr exon $3,5^{\prime}$-CCATATCCGTCGCCCTGTACGA-3', fgr exon 5, 5'-CTACTGATCTTTCCGAAGTAC-3', neo +mRNA, 5'-GCATCGCCTTCTATCGCCTTCTTGACG-3'. Quantitative RT PCR analysis 
of cytokine mRNAs (TNF- $\alpha$, TGF- $\beta$, IL-10, IL-12, MIP- $1 \alpha$, and iNOS) was performed as described (Reiner et al. 1993b), except that PCR conditions used were as described above. Macrophages were stimulated with INF- $\gamma$, LPS, zymosan, TNF- $\alpha$, heat-killed Listeria, or by in vitro infection with $L$. major. The amount of cDNA used in each experiment was normalized based on amplification of hypoxanthine phosphoribosyltransferase (Reiner et al. 1993b).

\section{Antibodies}

Rabbit antisera containing anti-Hck, Fgr, and Lyn antibodies were raised by immunization with Hck-glutathionine $S$-transferase (GST), Fgr-GST, and Lyn-GST fusion proteins. Regions coding for the unique domain of each kinase (hck amino acids 3-60; fgr amino acids 3-67, lyn amino acids 3-67) were cloned into the pGEX-2T GST expression vector and GST fusion proteins were produced in E. Coli as described (Grieco et al. 1992). Antisera was affinity purified by chromatography over columns containing the GST fusion protein covalently coupled to Affigel (Bio-Rad) and eluted with sequential glycine (pH 3.0) and triethylamine $(\mathrm{pH} 11.5)$ treatments as described (Harlow and Lane 1988) Antisera were used at $\sim 1 \mu \mathrm{g} / \mathrm{ml}$ for immunoblotting and at $1 \mu \mathrm{g} / 250 \mu \mathrm{g}$ of protein extract for immunoprecipitation. Anti-Src mAb 327 (Lipsich et al. 1983) was used for detection of Src. Antibodies for cell labeling were purchased from Boehringer and Pharmingen /either as FITC-labeled or biotin conjugated) and were used in FACS analysis as recommended by the supplier. Analysis was carried out on a FACSCAN flow cytometer (Becton-Dickinson).

\section{Phagocytosis assays}

Phagocytosis of sheep red blood cells (coated with rabbit antiSRBCs) was performed exactly as described (Greenberg et al. 1991). Macrophage-surface bound SRBCs were removed by hypotonic lysis, and intracellular SRBCs were detected by staining with Texas-red labeled goat anti-rabbit IgG. Phagocytosed SRBC were quantitated by counting $>100$ macrophages cells per sample. Phagocytosis of latex beads was performed as described (Oda and Maida 1986), except that cells were lysed in $0.2 \%$ Triton to allow protein measurement using the Bio-Rad protein assay. Maximal specific uptake (defined by uptake at $37^{\circ} \mathrm{C}$ vs. $4^{\circ} \mathrm{C}$ ) was observed at a ratio of 25 beads per cell. Fluorescence was converted to beads per cell using a standard curve of fluorescence versus a known number of beads. Fluorescent $2.0-\mu \mathrm{m}$ particles designed for phagocytic cell studies (Bioclean) were purchased from Duke Scientific (Palo Alto, CA).

\section{Cyotokines and $\mathrm{NO}_{2}{ }^{-}$assays}

TNF- $\alpha$ and IL- $1 \alpha$, secretion into macrophage culture media was assayed by ELISA using kits purchased from Genzyme. IL-6 ELISAs were performed by Stacy Fuchino at DNAX (Palo Alto, CA). Cells $\left(10^{6}\right)$ were cultured in 24-well dishes in $1 \mathrm{ml}$ of media (DMEM + 10\% FCS) with increasing concentrations of LPS for $16 \mathrm{hr}$, and $50-100 \mu \mathrm{l}$ of media was assayed for the above cytokines. The dose-response curve of cytokine production versus LPS concentration was compared among different cell types. The same cell culture medias were assayed for $\mathrm{NO}_{2}{ }^{-}$, a stable by-product of NO*, using a microplate assay in which $100 \mu \mathrm{l}$ of media was incubated with an equal volume of Griess reagent ( $1 \%$ sulfanilamide/0.1\% naphthylethylene diamine dihydrochloride $/ 2.5 \% \mathrm{H}_{3} \mathrm{PO}_{4}$ ) for $15 \mathrm{~min}$ at room temperature and absorbance was measured at $570 \mathrm{~nm}$ using sodium nitrite as a standard. LPS (E. coli K-235 from Sigma) concentrations used ranged from $0.1 \mathrm{ng} / \mathrm{ml}$ to $1 \mu \mathrm{g} / \mathrm{ml}$. Macrophage culture media were determined to be LPS free using the Limulus lysate assay (Microbiologic Associates) in which the minimal level of detection is $10 \mathrm{pg} / \mathrm{ml}$. Zymosan (Sigma) was used in concentration ranges of $5-100 \mu \mathrm{g} / \mathrm{ml}$, and heat-killed Listeria was used in a range of $10^{5}-10^{8} \mathrm{cfu} / \mathrm{ml}$ in macrophage activation experiments. INF- $\gamma$ was purchased from Genzyme.

\section{Respiratory burst}

The phorbol 12-myristate 13-acetate (PMA)-induced respiratory burst of thioglycollate-elicited and bone marrow-derived macrophages was assessed by reduction of cytochrome $c$ as described (Pick and Mizel 1981). Cells $\left(10^{5}\right)$ were cultured in 96well dishes with or without LPS, INF- $\gamma$, or TNF- $\alpha$ for $16 \mathrm{hr}$. Respiratory burst was stimulated by incubating cells with $1 \mu \mathrm{M}$ PMA in HBSS containing $100 \mu \mathrm{M}$ cytochrome $c$ for $2 \mathrm{hr}$, after which reduced cytochrome $c$ was measured at $550 \mathrm{~nm}$. Superoxide dismutase was added to some samples to confirm that reduction of cytochrome $c$ was $\mathrm{O}_{2}{ }^{-}$mediated.

\section{Tumoricidal assays}

Isolation and culture of NK and IL-2-activated LAK cells followed by tumoricidal assays was done exactly as described (Ryan et al. 1991). Tumor cell targets used were the P815 mastocytoma cell line, the YAC-1 lymphoma line, the B16L melanoma line, and the RI-1 T-cell lymphoma line. Tumoricidal activity of cultured macrophages was determined using the same assay, except that the macrophages were incubated with labeled target cells for $48 \mathrm{hr}$. Macrophages were either unactivated or activated by prior incubation with LPS for $16 \mathrm{hr}$ prior to culture with target cells.

\section{Macrophage signaling}

Macrophage cultures $\left(5 \times 10^{6}\right)$ were washed with PBS and incubated with DMEM, $0.2 \%$ BSA for $3 \mathrm{hr}$ at $37^{\circ} \mathrm{C} ; \mathrm{NaVO}_{3}$ was added to $100 \mu \mathrm{M}$ for $15 \mathrm{~min}$ and the cells were stimulated with LPS (100 ng/ml), PMA (100 nM), GM-CSF (40 ng/ml; Genzyme) or zymosan $(50 \mu \mathrm{g} / \mathrm{ml})$ for $15 \mathrm{~min}$. Signaling via Fc $\gamma R$ was assayed by incubation of cells with $10 \mu \mathrm{g} / \mathrm{ml}$ of anti-FcyRII/III $\mathrm{mAb} 2.4 \mathrm{G} 2$ (Pharmingen) or $50 \mu \mathrm{g} / \mathrm{ml}$ of murine $\mathrm{IgG}$ for $10 \mathrm{~min}$ followed by cross-linking with $80 \mu \mathrm{g} / \mathrm{ml}$ of rabbit anti-rat $\mathrm{F}\left(\mathrm{ab}^{\prime}\right)_{2}$ or $100 \mu \mathrm{g} / \mathrm{ml}$ of goat anti-mouse $\mathrm{F}\left(\mathrm{ab}^{\prime}\right)_{2}$ for $15 \mathrm{~min}$. Cells were washed once with PBS and lysed in $250 \mu \mathrm{l}$ of lysis buffer (150 mM NaCl, $10 \mathrm{~mm}$ Tris- $\mathrm{HCl}$ at $\mathrm{pH} 7.5,10 \mathrm{~mm}$ EDTA, $1 \%$ Triton X-100, $0.5 \%$ deoxycholate, $1 \mathrm{~mm} \mathrm{NaVO}{ }_{4}, 2 \mathrm{~mm}$ phenylmethylsulfonyl fluoride, $2 \mu \mathrm{M}$ leupeptin, $2 \mu \mathrm{M}$ pepstatin, $0.1 \%$ aprotinin), and extracts were prepared for immunoblot analysis for phosphotyrosine.

\section{Immunoblot analysis and in vitro kinase assays}

Bone marrow extracts were prepared by flushing marrow from femurs and tibias from pairs of animals with PBS $/ 0.2 \%$ BSA, followed by hypotonic lysis of RBCs, then lysis of leukocytes in $1 \mathrm{ml}$ of lysis buffer . Bone marrow-derived macrophages $\left(5 \times 10^{6}\right.$ cells) were lysed in $250 \mu \mathrm{l}$ of lysis buffer. Lysates were clarified by centrifugation for $15 \mathrm{~min}$ and protein determined by Bio-Rad protein assay. Extracts $(25 \mu \mathrm{g})$ were electrophoresed on $10 \%$ SDS-polyacrylamide gels (or $8 \%$ gels for total phosphotyrosine blots), and electrotransferred to nitrocellulose for $1 \mathrm{hr}$ at $0.4 \mathrm{~mA}$ as described (Harlow and Lane 1988). Filters were blocked with $2 \%$ BSA in Tris-HCl-buffered saline (TBS) $(\mathrm{pH} 7.5)$ for $1 \mathrm{hr}$ at room temperature and incubated with $1 \mu \mathrm{g} / \mathrm{ml}$ of affinity-puri- 
fied antiseras or anti-phosphotyrosine mAb 4Gl0 (from D. Kaplan, UBI Products/ in TBS, 2\% BSA, $0.2 \%$ Tween 20 for $16 \mathrm{hr}$ at $4^{\circ} \mathrm{C}$. Filters were washed extensively with TBS and incubated with horseradish peroxidase-conjugated anti-mouse antibody (Amersham) in TBS, 2\% BSA, $0.2 \%$ Tween 20 for $1 \mathrm{hr}$ at $4^{\circ} \mathrm{C}$, followed by washing, then developed using the Enhanced Chemiluminescence detection system (Amersham). Immunoprecipitations were carried out using $250 \mu \mathrm{g}$ of protein extract incubated with $1 \mu \mathrm{g}$ of antisera for $1 \mathrm{hr}$ at $4^{\circ} \mathrm{C}$ followed by incubation with protein A-coupled Sepharose beads (Sigma) for $30 \mathrm{~min}$ at $4^{\circ} \mathrm{C}$. Beads were washed extensively and incubated in kinase reaction buffer $\left(20 \mathrm{mM}\right.$ HEPES at $\mathrm{pH} 7.0,10 \mathrm{mM} \mathrm{MgCl}_{2}$, $10 \mathrm{~mm} \mathrm{MnCl} l_{2}, 0.5 \%$ Triton X-100) with $1 \mu \mathrm{Ci}$ of $\left[\gamma^{32} \mathrm{P}\right] \mathrm{ATP}$ for $15 \mathrm{~min}$. Reactions were stopped by washing beads in lysis buffer, and autophosphorylated proteins were elecrophoresed on $10 \%$ SDS-polyacrylamide gels.

\section{Infection studies}

The L. monocytogenes isolate was obtained from the Long Hospital (University of California, San Francisco). To ensure a standard inoculum, a single colony was grown in brain-heart infusion broth and a frozen stock (in $15 \%$ glycerol) was prepared. Repeated titer of the stock showed no change during the 6 months that experiments were conducted. Bacteria from the frozen stock were diluted into LB broth to give the desired inoculum and injected into animals intraperitoneally. At varying times following infection, animals were sacrificed and splenic and peritoneal homogenates were prepared. Animals that had already succumbed to the infection were not analyzed further. Tissues were homogenized in PBS and bacterial titers determined by serial dilution and culture on LB plates. Infection with L. major was performed as described (Reiner et al. 1993a).

\section{Acknowledgments}

We thank Jeanne Magram and Nancy Quintrell in Mike Bishop's laboratory for assistance with the hck clone; Paul Stein for assistance with ES cell transfections; Dorothy Bainton and Prem Handigama for help with pathological analyses; Stacy Fuchino for performing IL-6 ELISAs; Vivien Chan for preparing the anti-Lyn antisera; Jay Ryan and Erene Niemi for performing NK cell assays; Steve Reiner for infecting mice with Leishmania and for help with RT PCR experiments. C.A.L. is a Howard Hughes Medical Institute Physician Postdoctoral Fellow; P.S. is an Assistant Investigator of the Howard Hughes Medical Institute; H.E.V. is an American Cancer Society Research Professor. This work was supported by grants from the National Institute of Health to H.E.V. and P.S.

The publication costs of this article were defrayed in part by payment of page charges. This article must therefore be hereby marked "advertisement" in accordance with 18 USC section 1734 solely to indicate this fact.

\section{References}

Appleby, M.W., J.A. Gross, M.P. Cooke, S.D. Levin, X. Qian, and R.M. Perlmutter. 1992. Defective T cell receptor signaling in mice lacking the thymic form of p59fyn. Cell 70: 751-763.

Austyn, J.M. and S. Gordon. 1981. F4/80, a monoclonal antibody directed specifically against the mouse macrophage. Eur. J. Immunol. 11: 805-815.

Bagrodia, S., S.J. Taylor, and D. Shalloway. 1993. Myristylation is required for Tyr-527 dephosphorylation and activation of pp60 ${ }^{\mathrm{c}-s r c}$ in mitosis. Mol. Cell. Biol. 13: 1464-1470.
Bancroft, G.J., R.D. Schreiber, and E.R. Unanue. 1991. Natural immunity: A T-cell-independent pathway of macrophage activation, defined in the scid mouse. Immunol. Rev. 124: 524.

Beckerman, K.P., H.W. Rogers, J.A. Corbett, R.D. Schreiber, M.L. McDaniel, and E.R. Unanue. 1993. Release of nitric oxide during the $\mathrm{T}$ cell-independent pathway of macrophage activation: Its role in resistance to Listeria monocytogenes. I. Immunol. 150: 888-895.

Bolen, J.B. 1991. Signal transduction by the SRC family of tyrosine protein kinases in hemopoietic cells. Cell Growth Differ. 2: 409-414.

Bolen, J.B., R.B. Rowley, C.Spana, and A.Y. Tsygankov. 1992. The Src family of tyrosine protein kinases in hemopoietic signal transduction. FASEB $/$. 6: 3403-3409.

Boulet, I., S. Ralph, E. Stanley, P. Lock, A.R. Dunn, S.P. Green, and W.A. Phillips. 1992. Lipopolysaccharide- and interferongamma-induced expression of hck and lyn tyrosine kinases in murine bone marrow-derived macrophages. Oncogene 7: 703-710

Buchmeier, N.A. and R.D. Schreiber. 1985. Requirement of endogenous interferon- $\gamma$ production for resolution of Listeria monocytogenes infection. Proc. Natl. Acad. Sci. 82: 7404 7408.

Chomczynski, P. and N. Sacchi. 1987. Single-step method of RNA isolation by acid guanidinium thiocyanate-phenolchloroform extraction. Anal. Biochem. 162: 156-159.

Cooke, M.P., K.M. Abraham, K.A. Forbush, and R.M. Perlmutter. 1991. Regulation of $\mathrm{T}$ cell receptor signaling by a src family protein-tyrosine kinase (p59fyn). Cell 65: 281-291.

Cooper, J.A. and B. Howell. 1993. The when and how of Src regulation. Cell 73: 1051-1054.

Eiseman, E. and J.B. Bolen. 1992a. Engagement of the high-affinity IgE receptor activates src protein-related tyrosine kinases. Nature 355: 78-80.

- 1992b. Signal transduction by the cytoplasmic domains of Fc epsilon RI- $\gamma$ and TCR $-\zeta$ in rat basophilic leukemia cells. J. Biol. Chem. 267: 21027-21032.

Greenberg, S., K.J. el, E. Kaplan, and S.C. Silverstein. 1991. A fluorescence technique to distinguish attached from ingested erythrocytes and zymosan particles in phagocytosing macrophages. J. Immunol. Methods 139: 115-122.

Gresham, H.D., C.J. Ray, and F.X. O'Sullivan. 1991. Defective neutrophil function in the autoimmune mouse strain MRL/ lpr: Potential role of transforming growth factor-beta. $J$. Immunol. 146: 3911-3921.

Grieco, F., J.M. Hay, and R. Hull. 1992. An improved procedure for the purification of protein fused with glutathione S-transferase. BioTechniques 13: 856-857.

Gutkind, J.S., D.C. Link, S. Katamine, P. Lacal, T. Miki, T.J. Ley, and K.C. Robbins. 1991. A novel c-fgr exon utilized in Epstein-Barr virus-infected $\mathrm{B}$ lymphocytes but not in normal monocytes. Mol. Cell. Biol. 11: 1500-1507.

Hamada, F., M. Aoki, T. Akiyama, and K. Toyoshima. 1993. Association of immunoglobulin G Fc receptor II with Srclike protein-tyrosine kinase Fgr in neutrophils. Proc. Natl. Acad. Sci. 90: 6305-6309.

Handman, E., L.F. Schnur, T.W. Spithill, and G.F. Mitchell. 1986. Passive transfer of Leishmania lipopolysaccharide confers parasite survival in macrophages. I. Immunol. 137: 3608-3613.

Harlow, E. and D. Lane. 1988. Antibodies: A laboratory manual. Cold Spring Harbor Laboratory, Cold Spring Harbor, New York.

Hatakeyama, M., T. Kono, N. Kobayashi, A. Kawahara, S.D. Levin, R.M. Perlmutter, and T. Taniguchi. 1991. Interaction 
of the IL-2 receptor with the $s r c$-family kinase p56 $6^{\text {lck }}$ : Identification of novel intermolecular association. Science 252: 1523-1528.

Hoffmann, M.F. 1991. Drosophila $a b l$ and genetic redundancy in signal transduction. Trends Genet. 7: 351-355.

Holtzman, D.A., W.D. Cook, and A.R. Dunn. 1987. Isolation and sequence of a cDNA corresponding to a src-related gene expressed in murine haemopoietic cells. Proc. Natl. Acad. Sci. 84: 8325-8329.

Huang, S., H. Hendriks, A. Althage, S. Hemmi, H. Bluethmann, R. Kamijo, J. Vilcek, R.M. Zinkernagel, and M. Aguet. 1993. Immune response in mice that lack the interferon- $\gamma$ receptor. Science 259: 1742-1744.

Inoue, K., T. Yamamoto, and K. Toyoshima. 1990. Specific expression of human c-fgr in natural immunity effector cells. Mol. Cell. Biol. 10: 1789-1792.

King, F.J. and M.D. Cole. 1990. Molecular cloning and sequencing of the murine c-fgr gene. Oncogene 5: 337-344.

Kobayashi, N., T. Kono, M. Hatakeyama, Y. Minami, T. Miyazaki, R.M. Perlmutter, and T. Taniguchi. 1993. Functional coupling of the $s r c$-family protein tyrosine kinases p59 ${ }^{f y n}$ and $\mathrm{p} 53 / 56^{l y n}$ with the interleukin 2 receptor: Implications for redundancy and pleiotropism in cytokine signal transduction. Proc. Natl. Acad. Sci. 90: 4201-4205.

Law, D.A., M.R. Gold, and A.L. DeFranco. 1992. Examination of B lymphoid cell lines for membrane immunoglobulin-stimulated tyrosine phosphorylation and $s r c$-family tyrosine kinase mRNA expression. Mol. Immunol. 29: 917-926.

Ley, T.J., N.L. Connolly, S.Katamine, M.S. Cheah, R.M. Senior, and K.C. Robbins. 1989. Tissue-specific expression and developmental regulation of the human $f g r$ proto-oncogene. Mol. Cell. Biol. 9: 92-99.

Link, D.C., S.J. Gutkind, K.C. Robbins, and T.J. Ley. 1992. Characterization of the $5^{\prime}$ untranslated region of the human c-fgr gene and identification of the major myelomonocytic c-fgr promoter. Oncogene 7: 877-884.

Lipsich, L.A., A.J. Lewis, and J.S. Brugge. 1983. Isolation of monoclonal antibodies that recognize the transforming proteins of avian sarcoma viruses. J. Virol. 48: 352-360.

Lock, P., S. Ralph, E. Stanley, I. Boulet, R. Ramsay, and A.R. Dunn. 1991. Two isoforms of murine Hck, generated by utilization of alternative translational initiation codons, exhibit different patterns of subcellular localization. Mol. Cell. Biol. 11: 4363-4370.

Lowe, C., T. Yoneda, B.F. Boyce, H. Chen, G.R. Mundy, and P. Soriano. 1993. Osteopetrosis in Src-deficient mice is due to an autonomous defect of osteoclasts. Proc. Natl. Acad. Sci. 90: 4485-4489.

Mansour, S.L., K.R. Thomas, and M.R. Capecchi. 1988. Disruption of the proto-oncogene int- 2 in mouse embryo-derived stem cells: A general strategy for targeting mutations to nonselectable genes. Nature 336: 348-352.

Niwa, M., C.C. MacDonald, and S.M. Berget. 1992. Are vertebrate exons scanned during splice-site selection? Nature 360: $277-280$.

Notario, V., J.S. Gutkind, M. Imaizumi, S. Katamine, and K.C. Robbins. 1989. Expression of the $f g r$ protooncogene product as a function of myelomonocytic cell maturation. $/$. Cell Biol. 109: 3129-3136.

Oda, T. and H. Maida. 1986. A new simple fluorometric assay for phagocytosis. I. Immunol. Methods 88: 175-183.

Pick, E. and D. Mizel. 1981. Rapid microassays for the measurement of superoxide and hydrogen peroxide production by macrophages in culture using an automatic enzyme immunoassay reader. $/$. Immunol. Methods 46: 211-226.

Piwnica-Worms, H., K.B. Saunders, T.M. Roberts, A.E. Smith, and S.H. Cheng. 1987. Tyrosine phosphorylation regulates the biochemical and biological properties of pp $60^{\mathrm{c}-s r c}$. Cell 49: $75-82$.

Quintrell, N., R. Lebo, H. Varmus, M. Bishop, M.J. Pettenati, M.M. LeBeau, M.O. Diaz, and J.D. Rowley. 1987. Identification of a human gene (HCK) that encodes a protein-tyrosine kinase and is expressed in hemopoietic cells. Mol. Cell. Biol. 7: 2267-2275.

Reiner, S.L., Z. Wang, F. Hatam, P. Scott, and R.M. Locksley 1993a. $T_{h} 1$ and $T_{h} 2$ cell antigen receptors in experimental leishmaniasis. Science 259: 1457-1460.

Reiner, S.L., S. Zheng, D.B. Corry, and R.M. Locksley. 1993b. Constructing polycompetitor cDNAs for quantitative PCR. I. Immunol. Methods 115: 37-46.

Rudnicki, M.A., P.N.J. Schnegelsberg, R.H. Stead, T.Braun, H.H. Arnold, and R. Jaenish. 1993. MyoD or Myf-5 is required for the formation of skeletal muscle. Cell 75: 13511360.

Ryan, J.C., E.C. Niemi, R.D. Goldfien, J.C. Hiserodt, and W.E. Seaman. 1991. NKR-P1, an activating molecule on rat natural killer cells, stimulates phosphoinositide turnover and a rise in intracellular calcium. J. Immunol. 147: 3244-3250.

Sambrook, J., E.F. Fritsch, and T. Maniatis. 1989. Molecular cloning: A laboratory manual. Cold Spring Harbor Laboratory Press, Cold Spring Harbor, New York.

Scott, P. 1993. IL-12: Initiation cytokine for cell-mediated immunity. Science 260: 496-497.

Soriano, P., C. Montgomery, R. Geske, and A. Bradley. 1991. Targeted disruption of the c-src proto-oncogene leads to osteopetrosis in mice. Cell 64: 693-702.

Stefanova, I., M.L. Corcoran, E.M. Horak, L.M. Wahl, J.B. Bolen, and I.D. Horak. 1993. Lipopolysaccharide induces activation of CD14-associated protein tyrosine kinase $\mathrm{p} 53 / 56^{\mathrm{lyn}} \mathrm{J}$. Biol. Chem. 268: 20725-20728.

Stein, P.L., H.M. Lee, S. Rich, and P. Soriano. 1992. pp59fyn mutant mice display differential signaling in thymocytes and peripheral T cells. Cell 70: 741-750.

Straus, D.B. and A. Weiss. 1992. Genetic evidence for the in volvement of the lck tyrosine kinase in signal transduction through the T cell antigen receptor. Cell 70: 585-593.

te Riele, H., E.R. Maandag, and A. Berns. 1992. Highly efficient gene targeting in embryonic stem cells through homologous recombination with isogenic DNA constructs. Proc. Natl. Acad. Sci. 89: 5128-5132.

Tilney, L.G. and D.A. Portnoy. 1989. Actin filaments and the growth, movement, and spread of the intracellular bacterial parasite, Listeria monocytogenes. J. Cell Biol. 109: 15971608.

Willman, C.L., C.C. Stewart, T.L. Longacre, D.R. Head, R. Habbersett, S.F. Ziegler, and R.M. Perlmutter. 1991. Expression of the c-fgr and hck protein-tyrosine kinases in acute myeloid leukemic blasts is associated with early commitment and differentiation events in the monocytic and granulocytic lineages. Blood 77: 726-734.

Yi, T.L. and C.L. Willman. 1989. Cloning of the murine c-fgr proto-oncogene cDNA and induction of $c$-fgr expression by proliferation and activation factors in normal bone marrowderived monocytic cells. Oncogene 4: 1081-1087.

Ziegler, S.F., J.D. Marth, D.B. Lewis, and R.M. Perlmutter. 1987. Novel protein-tyrosine kinase gene (hck) preferentially expressed in cells of hemotopoietic origin. Mol. Cell. Biol. 7: 2276-2285.

Ziegler, S.F., C.B. Wilson, and R.M. Perlmutter. 1988. Augmented expression of a myeloid-specific protein tyrosine kinase gene (hck) after macrophage activation. I. Exp. Med. 168: $1801-1810$. 


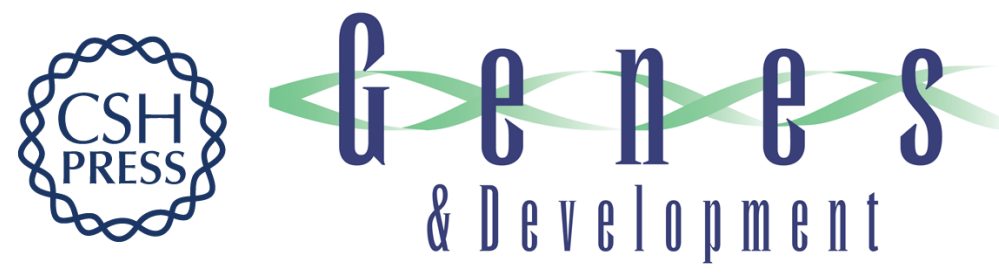

\section{Functional overlap in the src gene family: inactivation of hck and fgr impairs natural immunity.}

C A Lowell, P Soriano and $\mathrm{H}$ E Varmus

Genes Dev. 1994, 8:

Access the most recent version at doi:10.1101/gad.8.4.387

References This article cites 55 articles, 28 of which can be accessed free at:

http://genesdev.cshlp.org/content/8/4/387.full.html\#ref-list-1

License

Email Alerting

Service

Receive free email alerts when new articles cite this article - sign up in the box at the top right corner of the article or click here.

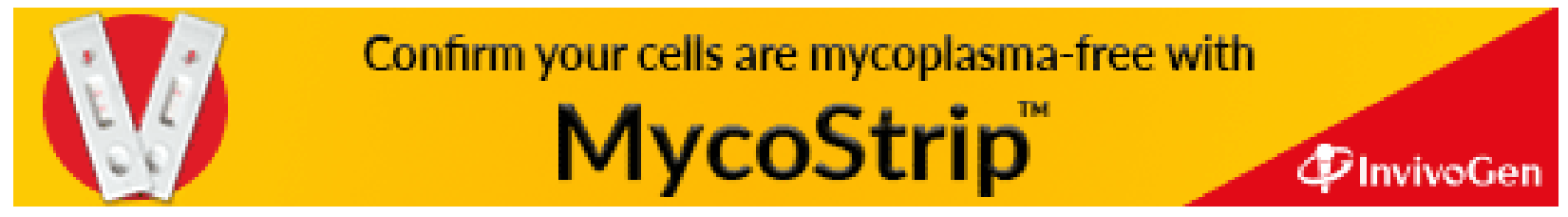

